\title{
Çalışan Sessizliği ve Algılanan Örgütsel Destek Arasındaki İlişkinin Veri Madenciliği ile İncelenmesi*
}

\author{
Investigating the Association between Employee Silence and \\ Perceived Organizational Support via Data Mining
}

\author{
Volkan Yüncü ${ }^{1}$ (1) Üzeyir Fidan² ${ }^{\circledR}$
}

*Bu makale 29 Haziran 2020 tarihinde çevrimiçi olarak düzenlenen 5. Uluslararası EMI Girişimcilik ve İletişim Sosyal Bilimler Kongresi adlı etkinlikte sözlü bildiri olarak sunulmuș ve özeti kongre bildiri özet kitabında basılmış "örgütsel sessizlik ve algilanan örgütsel destek arasindaki ilişkinin birliktelik kurallari analizi ile yeniden değerlendirilmesi" bașlıklı bildirinin geliștirilerek tamamlanmıș halidir.

${ }^{1}$ Afyon Kocatepe Üniversitesi, İktisadi İdari Bilimler Fakültesi, Afyonkarahisar, Türkiye

${ }^{2}$ Ușak Üniversitesi, Uzaktan Eğitim Meslek Yüksekokulu, Uşak, Türkiye

ORCID: V.Y. 0000-0001-5401-0683;

Ü.F. 0000-0003-3451-4344

Corresponding author:

Üzeyir FIDAN

Uşak Üniversitesi, Uzaktan Eğitim Meslek

Yüksekokulu, Uşak, Türkiye

Telephone: 0276221 2121/3360

E-mail address: uzeyir.fidan@usak.edu.tr

Submitted: 28.09 .2020

Revision Requested: 18.12 .2020

Last Revision Received: 30.12 .2020

Accepted: 30.12 .2020

Citation: Yüncü, V., ve Fidan, Ü. (2020). Çalışan sessizliği ve algılanan örgütsel destek arasındaki ilişkinin veri madenciliği ile incelenmesi. Acta Infologica, 4(2), 123-137.

https://doi.org/10.26650/acin.801398
ÖZ

İnsan davranışının kendine özgü bağlamlarda modellenmesi bugün özellikle pazarlama ve yönetim alanlarında yapılan araştırmalarda hayati önem taşımaktadır. Yönetim perspektifinden bakıldığında, çalışan davranışının modellenmesi karar vericilerin iş gücü planlaması ve yönetimi gibi pek çok konuda elini güçlendirmektedir. Elde edilen kapsamlı çalışan profilleri işletmelere başta sürdürülebilir rekabet üstünlüğü olmak üzere son derece önemli stratejik kazanımları sunmaktadır. Bu çalışma, çalışan sessizliği davranışı ile algılanan örgütsel destek arasındaki ilişkiyi veri madenciliği teknikleri aracılığıyla modellemeye yönelik öncül bir girişimdir ve bu bağlamda çalışan profili çıkarımı yapılmasını amaçlamaktadır. Bu iki önemli olgunun böyle bir ilişkisel bir çerçevede ele alınması örgütsel davranış araştırmacı için yeni bir kapı aralamaktadır. Çalışma kapsamında kullanılan ölçekler yardımıyla elde edilen verilerden bilgi keşfi yapabilmek için birliktelik kuralları analizi uygulanmıştır. Araştırma kapsamında çalşan profillerini temsilen elde edilen birlikteliklerin daha anlamlı olabilmesi için 0,50 eşik değeri üzerindeki kurallar değerlendirilmiştir. Bu doğrultuda, öncelikle örgütsel sessizlik ölçeğinin faktörleri arasındaki birliktelik kuralları değerlendirilmiş ve yedi kural elde edilmiştir. Daha sonra, algılanan örgütsel destek faktörü modele dahil edilerek elde edilen birliktelik kurallarını nasıl etkilediği incelenmiştir. Böylece her iki ölçeğin faktörlerinin bir arada oluşturduğu on birliktelik kuralı belirlenmiştir. Algılanan örgütsel destek faktörünün dahil olmasıyla araştırma için oldukça çarpıcı ilişkiler ortaya çıkarılmıştır. Özellikle ilk beş kuralda gözlemlenen \%80 üzerinde birliktelik ilişkisi, çalışan profillerinin belirlenmesi açısından gizli kalmış örüntülerin keşfedilmesini sağlamıştır. Çalışma kapsamında elde edilen bu değerli çıkarımlar gelecekte yapılacak profil çıkarımı çalışmaları için veri madenciliği tekniklerinin kullanımının önemini ortaya koymaktadir.

Anahtar kelimeler: Birliktelik Kuralları Analizi, Çalışan Sessizliği, Veri Madenciliği, Algılanan Örgütsel Destek, Apriori Algoritması

\footnotetext{
ABSTRACT

Modeling human behavior in distinctive contexts is of vital importance today, especially in research in the fields of marketing and management. From a management perspective, modeling employee behavior strengthens decision-makers' hands in numerous areas such as workforce planning and management. Comprehensive employee profiles obtained offer business organizations extremely important strategic gains, especially sustainable competitive advantage. This study is the first attempt to model the relationship between employee silence behavior and perceived organizational support through data mining techniques,
} 
and it aims to extract employee profiles accordingly. Evaluating these two important phenomena within such a relational framework opens a novel door for organizational behavior researchers. The Association Rule Mining technique was applied to achieve knowledge discovery from the data obtained through two scales. Within the research, the rules above a threshold value of 0.50 were evaluated to make the associations representing the employee profiles more meaningful. Accordingly, firstly, the association rules between the factors of the organizational silence scale were evaluated and seven rules were obtained. Next, the perceived organizational support factor was included in the model, and how it affected the obtained association rules was examined. In this manner, ten association rules formed by the factors of the two scales were determined. The inclusion of the perceived organizational support factor revealed quite striking relationships. Especially, an association of over $80 \%$ observed in the first five rules enabled the discovery of hidden patterns in terms of determining employee profiles. These valuable inferences obtained through this study reveals the importance of utilizing data mining techniques for future profile extraction studies.

Keywords: Association Rule Mining, Employee Silence, Data Mining, Perceived Organizational Support, Apriori Algorithm

\section{GíRiş}

Bugünün işletmelerinde yaygın olarak görülen çalışan sessizliği ve çalışanların örgütün çalışanların yaptığı katkıya ve çalışanların refahlarına ne derece değer verdiğini konu alan örgütsel destek teorisi (Shanock vd.,2019; Kurtessis vd., 2017; Rhoades ve Eisenberger, 2002; Eisenberger, Fasolo, ve Davis-LaMastro, 1990; Shore ve Shore, 1995) yöneticiler veya çalışanlardan gelen sinyallere odaklanan örgütsel davranış araştırmacılarının dikkatini çekmeye devam etmektedir. Literatürde yer bulan araştırmalar bu iki önemli olgunun sıklıkla birbirinden bağımsız olarak ve görece az olsa da ilişkisel bir perspektifle ele alındığını göstermektedir. Çalışan sessizliği ile ilgili yapılan son araştırmalarda çalışan sessizlik davranışı ile çalışan memnuniyeti ve bağl1lı̆̆ (Wang vd., 2020), narsist liderlik ve örgütsel sinizm (Mousa vd., 2020) ve algılanan stres ve güven (Dong ve Chung, 2020) arasındaki ilişkilerinin ele alındığı görülmektedir. Algılanan örgütsel destek ile ilgili yapılan son araştırmalarda ise, algılanan örgütsel destek ile çalışan performansı (Chen vd., 2020), işe bağl1lık (Imran vd., 2020) ve çalışan yaratıcılığı (Duan vd., 2020) arasındaki ilişkilerin incelendiği görülmektedir. Dolayısıyla, çalışan sessizliği ve algılanan örgütsel destek kavramları halen örgüt araştırmacılarının üzerinde çalışabileceği geniş birer alan sunmaktadır. Örneğin, çalışan sessizliğine olan akademik ilginin artmasına rağmen, örgütlerde çalışan sessizliğinin nedenleri, öncüleri, sonuçları ve çalışanların diğerlerinin sessizlik davranışına katılmanın sebepleri konusunda anlayışımızda hala önemli boşluklar bulunmaktadır (Whiteside ve Barclay, 2012). Benzer şekilde, Algılanan örgütsel destek ile performans, iş tatmini, örgütsel bağlılık vb. arasındaki ilişkileri konu alan araştırmalar halen geliştirilmeye açık geniş alanların varlığına işaret etmektedir. Her ne kadar örgütsel destek teorisi bağlamında yüksek düzeyde algılanan desteğin çalışanlar üzerindeki olumlu etkileri konusunda genel bir kanı oluşmuş görülse de (Chen vd., 2009) halen çok boyutlu, kapsamlı ve mevcut ilişkilerin yönünü açıklayan ilişkisel bir çerçevenin veya çerçevelerin varlığına ihtiyaç duyulmaktadır. Örneğin, teorinin temellerini atan Rhoades ve R. Eisenberger (2002) ortaya koydukları meta- analizde örgütsel destek ve performans ilişkisi ile ilgili çok çarpıcı bir ifade paylaşmaktadır. Bu noktada, çalışan performansı ile çalışanın algıladığı örgütsel destek arasında istatistiksel olarak anlamlı bir ilişki vardır. Fakat, bu çalışmada değerlendirilen araştırmalarda kullanılan metodolojik yaklaşımlar söz konusu ilişkilerin yönü ile ilgili herhangi bir net sonuç ortaya koyamamaktadır. Aslında, burada performans değişkeni üzerinden açığa vurulan sorunsalın örgütsel destek yazınında sıklıkla karşımıza çıkan psikolojik refah, çalışanların örgüte karşı tutumu ve çalışan davranışı gibi değişkenler (Allen, Shore ve Griffeth, 2003; Eisenberger vd., 1990; Rhoades ve Eisenberger, 2002 ) içinde geçerli olduğunu söylemek ilişkilerin yönü ve boyutu çerçevesinde mümkündür. Sonuç olarak, söz konusu iki önemli örgütsel olgunun olarak algılanan örgütsel destek ve çalışan sessizliği aralarındaki ilişkinin çok boyutlu ve alternatif teknikler kullanılarak incelenmesi ve ilişkilerin yönü ile ilgili kısıtların yeniden değerlendirilmesi literatürün olgunlaşması adına büyük önem taşımaktadır. Dolayısıyla, yapılan bu araştırma da söz konusu iki örgütsel olgu arasındaki ilişkinin belirlemesi amacıyla iki ölçek arasında keşfedilmemiş ilişkilerin açığa çıkarılması amacıyla elde edilen verilerle birliktelik kuralları analizi yapılmıştır. Bu şekilde, çalışan sessizliği ve algılanan örgütsel destek çerçevesinde bir çalışan profili çıkarımı yapılmıştır. Araştırma oldukça soyut görünen çalışan tutumlarının ve profillerinin açığa çıkarılması için yeni ve etkili bir yaklaşım sunmaktadır. 


\section{KURAMSAL ÇERÇEVE}

\section{1. Çalışan Sessizliği}

Çalışanlar işletmelerin başarılı olabilmesi için son derece hayati olan değişim, yaratıcılık, öğrenme ve inovasyon gibi kritik faktörlerin kaynağı olarak değerlendirilmektedir (Beheshtifar vd., 2012:275). Bunun sebebi, çalışanların örgütte sürdürülen iş ve iş organizasyonlarını iyileştirmek için gerekli olan yapıcı fikir, bilgi ve görüşlere sahip olmasıdır (Zehir ve Erdoğan, 2011). Örgütlerin gelişiminde bu gibi fikir, bilgi ve deneyimlerin sesli olarak paylaşılmasının rolü büyüktür. Öte yandan, çoğu durumda çalışanların örgütlerinde kendilerini doğrudan ilgilendiren veya ilgilendirmeyen konulardaki düşüncelerini dile getirmek yerine sessiz kalmayı tercih ettikleri ve örgütlerindeki önemli sorunlardan bahsetmek yerine çeşitli sebeplerle fikirlerini dışa vurmaktan çekindikleri de bir gerçektir. Her ne kadar örgüt ve insan kaynakları yönetimi perspektifi örgütün gelişimi ile örgütsel alandaki açık diyaloğun arasındaki doğrusal ilişki konusunda belirli savları benimsemiş olsa da uygulamada çok sayıda çalışanın söz konusu açık diyaloğa örgütün desteğini alamama korkusuyla sıcak bakmadığını ve bu tip bir bilgi alışverişine kuşkuyla yaklaştığını ifade eden çeşitli çalışmalar olduğu görülmektedir (Karakaş, 2019). Bu çerçevede, araştırmacılar çalışanların ne zaman ve nasıl bu iki tercih arasında kaldığını araştırmakta ve son yıllarda örgütsel davranış alanında çalışan sessizliği veya örgütsel sessizlik başlıkları altında giderek olgunlaşan bir literatür karşımıza çıkmaktadır (Donaghey vd., 2011). Çalışan sessizliği literatürüne genel ve kapsayıcı bir çerçeve içerisinde baktığımızda, aslında bu literatürün Morrison ve Milliken (2000), Milliken, Morrison ve Hewlin (2003) ve Pinder ve Harlos (2001) tarafından yapılan araştırmalara dayandı̆̆ı görülmektedir (Çınar vd., 2013:315).

Sessizlik konusunda üst yönetimin rolüne özellikle vurgu yapan Morrison ve Milliken (2000)'e göre çalışan sessizliği çalışanların örgüt hakkındaki potansiyel sorunlar hakkında kasıtlı olarak bilgi, görüş, öneri veya endişeleri saklaması anlamına gelmektedir. Çalışan sessizliğinin birçok iş yerinde neden sistemik bir hal aldığını ve sessizliğin ortaya çıkmasında etkili norm ve güçleri açıklamayı amaçlayan Morrison ve Milliken(2000)'e göre, çalışan sessizliği örgüte zarar veren kolektif bir olgudur. Örgütün üyeleri örgütü ilgilendiren konu ve/veya sorunlarla ilgili sessiz kalmayı tercih ederlerse bu sessizlik davranışı kolektif bir davranış biçimini alır. Bu anlamda çalışan sessizliği toplantı ve görüşmelerde sessiz kalma, önerilerin tartışıldığı platformlara düşük katılım veya düşük kolektif ifade gibi biçimlerde ortaya çıkabilmektedir (Huang vd., 2005).

Milliken, Morrison ve Hewlin (2003:1467) çalışanların sessiz kalmayı tercihini gösteren bir model önermektedir. Daha ayrıntılı bir ifadeyle, araştırmacılar burada çalışanların fikir, duygu ve düşüncelerini dillendirmenin algılanan sonuçlarının sessizliğe nasıl bir katkıda bulunduğuna ve konuşmanın sosyal ve ilişkisel etkilerine dair bir model ortaya koymuşlardır. Bu çerçevede, çalışan sessizliğinin iş tatminini azaltması, devamsızlık oranını artırması ve işten ayrılma süresini azaltması vb. sebeplerle örgütler için son derece zararlı olduğu ileri sürülmektedir (Çınar vd., 2013:316). Araştırmacılar bu doğrultuda örgüt üst yönetimi çalışanların örgütü ilgilendiren önemli konular hakkında konuşmasını sağlayabilmek adına öneriler getirmektedirler (Milliken vd., 2003:1473).

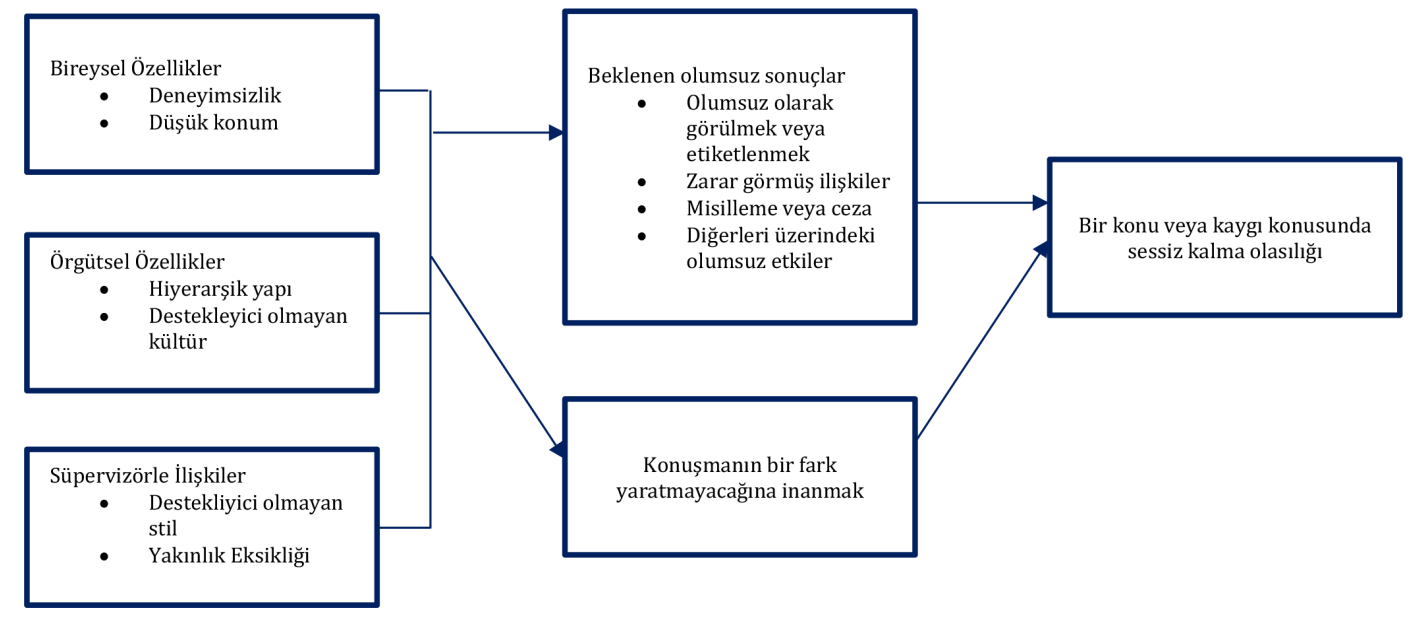

Şekil 1. Sessiz kalma modeli (Milliken vd., 2003:1467) 
Son olarak, Pinder ve Harlos (2001), çalışan sessizliğini bir çalı̧anın kendi davranışsal, bilişsel ve duygusal değerlendirmelerini mevcut bir sorun durumunun üstesinden gelebilecek örgüt üyeleriyle paylaşmaması olarak tanımlamaktadır. Araştırmacılar Hirschman (1970) tarafından önerilen ses (voice) ve sessizlik (silence) kavramları arasındaki ilişkiyi çalışanların memnuniyetsizlik duygusunu nasıl ifade ettiklerini yansıtmanın bir yolu olarak ele almış ve çalışanların endişelerini anlamakla ilgili olduğunu belirtmişlerdir (Beheshtifar vd., 2012:277). Pinder ve Harlos (2001) fikir ve düşünceleri seslendirmenin faydasız veya tehlikeli olarak algılandığı örgütlerde, çalışanlar arasında bir sessizlik ikliminin muhtemel olduğunu savunmaktadır (Donaghey vd., 2011:53). Pinder ve Harlos (2001)'a göre çalışan sessizliği bilginin kasıtlı bir biçimde seslendirilmemesi ve çalışanların kendini koruma amaçlı muhtemel olumsuz sonuçlarla karşılaşma korkusu olmak üzere iki biçimde gerçekleşmektedir (Chou ve Chang,2017:4). Böylece, Pinder ve Harlos (2001) çalışan sessizliğini bir dizi biliş, duygu veya niyetle ilişkilendirmiş ve bir olgu olarak çalışan sessizliğinin altında yatan nedenlere bağlı olarak farklı anlamlar kazabileceğini ifade etmiştir. Başka bir ifadeyle, çalışan sessizliğinin olumlu veya olumsuz işyeri bağlamlarında ortaya çıkabilecek çok boyutlu bir davranış olarak değerlendirmişleridir. Çalışan sessizliğinin karmaşık ve çok boyutlu yapısını ortaya koyması bakımından bu yaklaşım oldukça önemlidir. Nitekim, sessizliğin kimi biçimleri stratejik ve proaktif olabilmektedir (Van Dyne vd., 2003).

Çalışan sessizliği literatürünün köşe taşları olarak değerlendirilen bu üç önemli çalışmaya ek olarak, Van Dyne vd. (2003)'e ve yazarların bu araştırmada da kullandığımız sessizlik tipolojisine değinmek gerekmektedir. Burada Van Dyne vd. (2003) çalışanların güdülerine dayanarak, üç tip sessizliğin olduğunu öne sürmektedir: Kabullenici sessizlik (Acquiescent Silence), korunmacı sessizlik (Defensive Silence) ve korumacı sessizlik (ProSocial Silence). Buradaki Kabullenici sessizlik kavramı aslen Pinder ve Harlos'a (2001) dayanmaktadır. Pinder ve Harlos’a (2001:350) göre, kabullenici çalışanlar neredeyse gönüllü olarak sessiz olma eğilimi göstermekle birlikte kendileri bu durumun farkında dahi değildirler. Statükoya olan tolerans nispeten yüksektir ve bu durumlarını da normal olarak görürler. Van Dyne vd. (2003:1366) de bu bağlamda kabullenici sessizliği çalışanların istifaya dayalı olarak ilgili fikirleri, bilgileri veya fikirleri saklamak olarak tanımlamaktadır ve daha çok pasif olan bağımsız davranışlar olarak değerlendirmektedir. Öte yandan, Kabullenici sessizliği aksine, korunmacı sessizlik çalışanların kendilerini dış tehditlerden koruma amacıyla gösterdikleri bilinçli ve proaktif bir davranıştır (VanDyne vd., 2003:1367;Schlenker ve Weigold, 1989). Bu anlamda daha proaktif bir davranışa işaret eden korunmacı sessizlik farkındalık ve ilgili alternatiflerin de dikkate alınarak değerlendirilmesini içerir ve çalışan tarafından alınan bilinçli bir karar anlamını taşımaktadır (Van Dyne vd., 2003:1367). Son olarak, korumacı sessizlik da tıpkı korunmacı sessizlik davranışı gibi bilinçli ve proaktif bir davranışı temsil etmektedir. Ancak, korunmacı sessizlikten ayrıldığı nokta, çalışanın gösterdiği bilinçli sessizlik davranışının amacının kendini korumaktan öte, bir nevi diğerkâmlık örneği olarak örgütteki diğer kişilerin veya örgütün çıkarlarını korumak amacını gütmesidir (Van Dyne vd.,2003:1368).

\subsection{Algılanan Örgütsel Destek}

Algılanan örgütsel destek, çalışanların çalışmakta oldukları işletmenin çalışanların örgüte olan katkılarına ne ölçüde değer verdiğini ve refahlarını önemsediğine ilişkin algısını ifade etmektedir (Shanock vd., 2019). Yapılan algılanan örgütsel destek tanımlarının çalışanların örgüte olan katkısına verilen değer ve örgütün çalışanların refahına verdiği önem özellikle vurgulanan iki boyutu oluşturmaktadır. Algılanan örgütsel destekle ilgili çalışmalara bakıldığında kavramın özellikle Eisenberger, Huntington, Hutchinson ve Sowa tarafından 1986 yılında yayımlanan makale ile birlikte bir ilgi alanı olarak ortaya çıktığ 1 görülmektedir. Bu çalışmada yazarlar üç önemli bulguyu öne çıkarmaktadır. Buna göre, çalışanlar örgütün katkılarına ne ölçüde değer verdiğine ve refahına önem verdiğine ilişkin inançlar oluştururlar, bu yönde algılanan örgütsel destek devamsızlığ1 azaltır ve algılanan örgütsel destek ve devamsızlık arasındaki ilişki, güçlü değişim ideolojisi olan çalışanlar için zayıf değişim ideolojisi olan çalışanlardan daha fazladır (Eisenberger vd., 1986). Bu çalışma ile birlikte algılanan örgütsel desteğin çalışanların gösterdikleri performans ve refah düzeyleri üzerinde etkisini ele alan çalışmalar artarak devam etmiş̧tir. Örgütsel destek teorisine göre (Eisenberger vd.., 1986; Eisenberger ve Stinglhamber, 2011; Rhoades ve Eisenberger, 2002; Shore ve Shore, 1995) algılanan örgütsel destek çalışanların örgütün kendilerine karşı olumlu ya da olumsuz davranışların arkasındaki niyetine ilişkin inanışlarına bağlıdır. Algılanan örgütsel desteğin gelişimini, doğasını ve sonuçlarını inceleyen örgütsel destek teorisi esasen Levinson'un (1965) çalışanların örgütü kişileştirdiğini ve örgütün kendilerine yönelik iyi veya kötü niyetli niyetleri de içeren eğilimli özelliklere sahip olduğuna inandıklarını varsayan olduğu görüşünü benimsemektedir (Hayton 
vd., 2012:235). Bu anlamda algılan örgütsel destek çalışanların kendilerini örgütün hedeflere ulaşmasına yardım etmek zorunda hissettiği ve örgüt lehine artırdıkları çabanın da daha büyük ödüller getireceği düşünülen bir sosyal değişim (mübadele) süreci başlatır. Söz konusu sosyal değişim süreci içerisinde algılanan örgütsel destek aynı zamanda sosyo-duygusal ihtiyaçların karşılanmasına ve çalışanların örgütle özdeşleşerek olan örgüte olan bağlılığını artmasına olanak sağlamaktadır (Kurtesis vd., 2015:2). Bu süreçte ücret artışı, gelişimsel eğitim fırsatları gibi birtakım ödül ve kazanımları elde eden çalışanlar algıladıkları örgütsel desteğe karşılık olarak örgütün amaç ve hedeflerine ulaşmasını sağlamak için ellerinden geleni yaparlar (Neves ve Eisenberger, 2014:189). Başka bir ifadeyle, çalışan ve örgüt arasındaki sosyal mübadele karşılıklılık normu temelinde örgütlerinden iyi muamele gören çalışanların yüksek bağlılık ve çaba ile yanıt verdiğini göstermektedir (Eisenberber vd., 2014:635). Bu çalışanlar doğal olarak, daha fazla psikolojik refah, örgüte karşı daha olumlu bir yönelim ve örgüte yardımcı olma amaçlı davranışlar sergilemektedir (Hayton vd., 2012:235). Yüksek algılanan örgütsel destek düzeyine sahip çalışanların işlerini daha olumlu değerlendirdiğini (Artan iş tatmini, daha iyi ruh hali, daha az stres) ve bu çalışanların örgütlerine daha fazla katkı yaptıklarını (artan örgütsel bağlılık, artan performans, azalan çalışan devir oranı) gösteren çok sayıda çalışma vardır (Chen vd., 2099:120).

\section{3. Çalışan sessizliği ve Algılanan Örgütsel Destek İlişkisi}

Her ne kadar birbirlerinden bağımsız olarak çok sayıda araştırmaya konu olmuşlarsa da çalışan sessizliği ve algılanan örgütsel destek kavramlarının kuramsal argümanlar ve/veya ampirik bulgular eşliğinde birlikte ele alındığı araştırma sayısının görece az olduğu görülmektedir. Kronolojik bir perspektifle baktığımızda göze çarpan belli başlı çalışmalar bu iki olgunun arasındaki ilişkiyi farklı bağlamlarda değerlendirmişlerdir. Tucker vd. (2008) algılanan örgütsel destek ve algılanan iş arkadaşı desteğinin çalışanların iş yeri güvenliği ile ilgili fikirlerini seslendirmesinde önemli rolü olduğuna işaret etmektedir. Araştırmacılar güvenli çalışma koşulları bağlamında algılanan örgütsel destek ve çalışanların sessizliği arasındaki ilişkide iş arkadaşı desteğinin aracılık rolünü ele almış ve iş arkadaşlarının güvenlikle ilgili konularda konuşmak için diğerlerini teşvik etme noktasında önemli bir rolü olduğunu belirtmişlerdir. Aynı yıl içerisinde Tangirala ve Ramanujam (2008) prosedürel adalet ikliminin çalışan sessizliği üzerindeki etkilerini incelenmiş ve örgüt içerisindeki prosedürel adalet iklimi yüksek olduğunda ve çalışanların çalışma gruplarıyla özdeşleştiklerinde işlerine olan bağlılıklarının ve çalışan sesliliğini arttığını ifade etmişlerdir. Benzer şekilde, Wang ve Hsieh (2013) örgütsel etik iklimin çalışanların sessizliğine olan etkisini inceledikleri çalışmada bir örgütsel etik iklim tipi olarak araçsal iklimin kabullenici sessizlikle pozitif bir ilişsisi olduğunu göstermiştir.

Ayrıca, diğer iki örgütsel etik iklim tipi ile kabullenici ve korunmacı sessizlik arasında negatif yönlü ilişki olduğunu gözlemlemişlerdir. Singh ve Malhotra (2015) çalışanın algıladığı örgütsel destek ve çalışan sessizliği arasındaki ilişkide güven değişkeninin aracılık etkisini ele almıştır. Araştırmacılar algılan örgütsel destek ve güvenin örgütsel sessizlikle olan negatif ilişkisine dair ve algılanan örgütsel destekle örgütsel güven arasında pozitif yönlü bir ilişkinin varlığından bahsetmektedir. Yu ve Liu (2016) psikolojik sermaye ve algılanan örgütsel desteğin çalışanların inovasyon ve sessizlik davranışları üzerindeki etkisini araştırmış ve psikolojik sermaye ve algılanan örgütsel desteğin sessizlik davranışları üzerinde olumsuz etkileri varken inovasyon davranışları üzerinde olumlu etkileri olduğunu ifade etmişlerdir. Çalışan sessizliğinin karar verme süreçlerinin kalitesine zarar verdiğinin altı çizilen araştırmada çalışanların sessiz kalma davranışının altında yatan temel nedeni işlerini korumak istemeleri olduğu ifade edilmektedir. Bu çerçevede, algılanan örgütsel desteğin yüksek olduğu durumlarda, çalışanların bağlılıklarının artmasının yanı sıra, psikolojik güvenlik duygusuna sahip çalışanlar karar alma süreçlerinde aktif olarak katılmaktan memnuniyet duyduğu ifade edilmektedir. Aynı yıl yapılan bir diğer araştırmada ise Khalid ve Ahmed (2016) örgütsel politika bağlamında çalışanların sessizliğinin ardındaki önemli nedenlere odaklanmış ve süpervizöre duyulan güvenin bu ilişkiyi etkileyip etkilemediğini araştırmışlardır. Bulgular süpervizöre olan güvenin bu ilişkide kayda değer bir aracılık rolü olmadığını ama örgütsel politika ile çalışanların sessiz kalma nedenleri arasında pozitif bir ilişki olduğunu göstermektedir. Son olarak, Akçin vd. (2017) örgütsel desteğin çalışanların sessizliği ve görev performansı üzerindeki etkisini ele almış ve örgütsel desteğin görev performansı üzerindeki etkisini incelemiştir. Bulgular algılanan örgütsel destek ile kabullenici ve korunmacı sessizlik arasında negatif bir ilişki varken, korumacı sessizlikle arasında pozitif bir ilişki olduğunu göstermektedir. 


\section{ARAŞTIRMA PROBLEMİ KURGUSU}

Araştırmada kabullenici, korunmacı, korumacı ve algılanan örgütsel destek (destek) faktörleri düşük, orta ve yüksek olarak seviyelendirilmiştir. Önceki çalışmalarda bu faktörler arasındaki korelasyonlar detaylı bir şekilde incelenmiştir. Bu çalışmada ise çalışanların verdiği cevaplar doğrultusunda belirtilen faktörlere hangi seviyelerde birlikte ve ortak bir algı oluştuğu saptanmaya çalışılmıştır. Böylece, araştırma problemi kurgulanırken aşağıda belirtilen hipotezler baz alınmıştır:

$\mathrm{H}_{1}$ : Kabullenici sessizlik seviyesi düşük/orta/yüksek olan çalışanın algılanan örgütsel destek seviyesi de düşüktür/ortadır/ yüksektir.

$\mathrm{H}_{2}$ :Korunmacı sessizlik seviyesi düşük/orta/yüksek olan çalışanın algılanan örgütsel destek seviyesi de düşüktür/ortadır/ yüksektir.

$\mathrm{H}_{3}$ : Korumacı sessizlik seviyesi düşük/orta/yüksek olan çalışanın algılanan örgütsel destek seviyesi de düşüktür/ortadır/ yüksektir.

$\mathrm{H}_{4}$ : Kabullenici, Korunmacı ve Kabullenici sessizlik faktörleri arasında aynı seviyede birliktelik ilişkileri bulunmaktadır.

$\mathrm{H}_{5}$ : Kabullenici ve Korunmacı sessizlik seviyesi düşük/orta/yüksek olan çalışanın algılanan örgütsel destek seviyesi de düşüktür/ortadır/yüksektir.

$\mathrm{H}_{6}$ : Kabullenici ve Korumacı sessizlik seviyesi düşük/orta/yüksek olan çalışanın algılanan örgütsel destek seviyesi de düşüktür/ortadır/yüksektir.

$\mathrm{H}_{7}$ : Korunmacı ve Korumacı sessizlik seviyesi düşük/orta/yüksek olan çalışanın algılanan örgütsel destek seviyesi de düşüktür/ortadır/yüksektir.

$\mathrm{H}_{8}$ : Kabullenici, Korunmacı ve Korumacı sessizlik seviyesi düşük/orta/yüksek olan çalışanın algılanan örgütsel destek seviyesi de düşüktür/ortadır/yüksektir.

Böylece verilen hipotezler, faktörler arasında yer alan ilişkileri belirleyen korelasyon araştırmalarından farklı olarak aynı seviyede yer alan birliktelikleri araştırmak ve var olan gizli örüntüleri ortaya çıkararak çalışanların profillerini ortaya koymayı amaçlamaktadır. Bu noktada, araştırmada uygulanan yöntemin öncül korelasyon çalışmalarından önemli üstünlükleri olduğunun altını çizmek gerekmektedir. Öncelikle, korelasyon analizi verilen faktörler arasındaki ilişkinin gücü ve yönü konularında bilgi verirken, araştırmada uygulanan veri madenciliği tekniği ile katılımcıların her birinin vermiş olduğu yanıtlar ayrı ayrı değerlendirilerek tüm örneklem hacminde hangi ağırlıkta veya ağırlık aralığında birliktelik gösterdikleri bilgisi elde edilmektedir. Ayrıca, korelasyon analizinde verilerin tamamı üzerinden iki faktör arasındaki genel ilişki hakkında bilgi edinilirken, birliktelik analizi ile tam anlamıyla aynı yönlü ilişkilerin var olduğu durumlar üzerinden değerlendirmeler yapılmaktadır.

Tablo 1

Faktörler arası korelasyon analizi

\begin{tabular}{|c|c|c|c|c|c|}
\hline & & Kabullenici & Korunmacı & Korumacı & Destek \\
\hline \multirow{3}{*}{ Kabullenici } & Pearson Korelasyon Katsayısı & 1 & & & \\
\hline & Önem Seviyesi (2-yönlü) & & & & \\
\hline & Gözlem Sayısı (n) & 504 & & & \\
\hline \multirow{3}{*}{ Korunmaci } & Pearson Korelasyon Katsayısı &, $536^{* *}$ & 1 & & \\
\hline & Önem Seviyesi (2-yönlü) & 0,000 & & & \\
\hline & Gözlem Sayısı (n) & 504 & 504 & & \\
\hline \multirow{3}{*}{ Korumacı } & Pearson Korelasyon Katsayısı & ,233* & $257^{* *}$ & 1 & \\
\hline & Önem Seviyesi (2-yönlü) & 0,000 & 0,000 & & \\
\hline & Gözlem Sayısı (n) & 504 & 504 & 504 & \\
\hline \multirow{3}{*}{ Destek } & Pearson Korelasyon Katsayısı &, $366^{* * *}$ & $456^{* *}$ & $200^{* *}$ & 1 \\
\hline & Önem Seviyesi (2-yönlü) & 0,000 & 0,000 & 0,000 & \\
\hline & Gözlem Sayısı (n) & 504 & 504 & 504 & 504 \\
\hline
\end{tabular}

** Korelasyon değerleri 0,01 anlamlılık düzeyinde (2 yönlü) anlamlıdır. 
Korelasyon katsayısı (r) [-1, 1] aralığında değerler almaktadır. Korelasyon katsayısının işareti, ilgili iki değişken arasındaki ilişkinin yönünü göstermektedir. İlişkinin gücünün yorumlanabilmesi için ise korelasyon katsayısının mutlak değerce büyüklüğü yorumlanmalıdır. Hesaplanan korelasyon katsayısı $|\mathbf{r}|<=0,39$ genellikle düşük veya zayıf korelasyon, $[0,40,0,69]$ aralığındaki korelasyon değerleri orta seviye ve son olarak $|r|>=0,70$ değeri ise güçlü veya yüksek korelasyon olarak yorumlanmaktadır (Schober vd., 2018). Tablo 1 incelendiğinde kabullenici faktörünün korunmacı faktörü ile arasında pozitif yönlü orta güçlü bir ilişki $(\mathrm{r}=0,536)$, korumacı faktörü ile arasında pozitif yönlü zayıf bir ilişki $(\mathrm{r}=0,233)$ ve destek faktörü ile arasında ise pozitif yönlü zayıf bir ilişki $(r=0,366)$ olduğu görülmektedir. Ayrıca korunmacı faktörünün korumacı faktörü ile arasında pozitif yönlü zayıf bir ilişki $(r=0,257)$ ve destek faktörü ile arasında da pozitif yönlü orta güçlü bir ilişki $(r=0,456)$ olduğu görülmektedir. Son olarak korumacı ve destek faktörleri arasında pozitif yönlü zayıf bir ilişki $(r=0,200)$ gözlemlenmektedir.

\section{YÖNTEM}

\subsection{Veri Madenciliği}

Veri bilimi, 20. yüzyılda sadece akademik bir çalışma alanı olarak görülmekteyken, sürekli artan verinin işlenme ihtiyacı ve gerekli teknolojinin de gelişmesiyle birlikte farklı uygulama alanlarında yaygınlaşmaktadır. Özellikle işletmelerde, insan davranışının modellenmesi, pazarlama ve yönetim gibi işletme fonksiyonlarında yapılan araştırmalarda hayati önem taşımaktadır. Geçmişte insan davranışı ile ilgili verileri toplamak hem çok zor hem de maliyetli olduğundan çalışmalar daha kısıtlı kalmıştır. Gelişen teknolojik imkânlar ile güvenilir veri toplamanın maliyetleri azalmaktadır. Bu sayede her geçen gün artmaya devam eden çok büyük miktarda veri elde edilmiş ve elde edilmeye devam etmektedir. Aslında veri toplama sorunu yerini verilerin işlenmesi problemine bırakmaktadır. Sürekli artan veri nedeniyle, araştırmacılar yararlı ve anlamlı bilgiler elde etme sürecinde zorluklarla karşılaşmaktadır (Aggarwal, 2015). Veriden bilgiye dönüşüm süreci problemin özünü anlamak ve anlamlandırmak için büyük önem taşımaktadır. Bu kapsamda veri madenciliği, elde edilen verilerde gizlenmiş, önceden bilinmeyen ve potansiyel olarak yararlı olan bilgilerin ortaya çıkarılması için uygulanan adımların genel ifadesi olarak tanımlanmaktadır (Aggarwal, 2015; Bramer, 2007). Fakat bir problemin veri madenciliği ile çözümü, verinin doğru şekilde toplanması, gerekli ön işlemlerin yapılması süreçleriyle doğrudan ilgilidir. Bir diğer önemli problem ise yapılan araştırmaya bağlı olarak toplanan verilerin sayısallaştırılması sürecidir. Özellikle sosyal tutum gibi davranış örüntüleri, öngörülen tutum ya da eğilim, belirlenmiş sosyal durumlara yatkınlık gibi soyut veri tipleri her zaman nümerik olarak elde edilememektedir (Lapiere, 1934). Bu sebeple insanların tutum ya da davranışları ile ilgili veri toplayabilmek için genellikle anket en önemli araçlardan biri olarak tercih edilmektedir.

\subsection{Veri Toplama}

Bu çalışmada kullanılan ölçeklerden biri, Van Dyne, Ang ve Botero (2003) tarafından geliştirilen kabullenici, korunmacı ve korumacı sessizlik olmak üzere 3 faktörden oluşan örgütsel sessizlik ölçeğidir. Çalışmada kullanılan diğer ölçek ise Shanock vd. (2019) tarafından geliştirilen ve tek faktörlü algılanan örgütsel destek ölçeğidir. Araştırmada kullanılan veri toplama araçlarının etik açıdan sakıncalı olmadığına Afyon Kocatepe Üniversitesi Bilimsel Araştırma ve Yayın Etiği Kurulu'nun 27.05.2020 tarihli ve 2020/76 sayılı kararı ile karar verilmiştir. Araştırmada, mavi yaka otel çalışanlarına yöneltilen iki ölçek soruları ve demografik sorulardan elde edilen veriler ile veri madenciliği yaklaşımlarından birliktelik analizi kullanılarak çalışanların profil çıkarımı yapılması üzerinde durulmaktadır. Karar vericilerin, çalışan profilini doğru modelleyerek sürekliliği ve dolayısı ile gerekli iyileştirmeleri yapması beklenmektedir. Bu sebeple ulaşılan çalışan profilleri, gerek iş gücü planlaması için gerekse iş gücü yönetiminde önem arz etmektedir. Örgütsel sessizlik ölçeğinde 3 faktörü ölçebilmek için 15 madde, algılanan örgütsel destek ölçeğinde ise tek faktörü ölçebilmek için 10 madde kullanılmıştır. 513 anketten elde edilen veri setinde kayıp değerlerin olduğu gözlemler araştırmadan çıkarılmış ve 504 anket her bir ölçek için ayrı ayrı güvenirlik analizleri yapılmış ve Tablo2'de verilmiştir. 
Tablo 2

Ölçeklere göre güvenirlik analizleri

\begin{tabular}{|c|c|c|c|c|c|}
\hline $\begin{array}{l}\text { Örgütsel Sessizlik Ölçeği } \\
\text { (3 Faktör - } 15 \text { Madde) }\end{array}$ & $\begin{array}{l}\text { Cronbach's } \\
\text { Alpha }\end{array}$ & $\begin{array}{l}\text { Algılanan Örgütsel Destek Ölçeği } \\
\text { (1 Faktör - } 10 \text { Madde })\end{array}$ & $\begin{array}{c}\text { Cronbach's } \\
\text { Alpha }\end{array}$ & $\begin{array}{c}\text { Toplam } \\
\text { (4 Faktör - } 25 \text { Madde) }\end{array}$ & Cronbach's Alpha \\
\hline $\mathrm{n}=504$ & 0,74 & $\mathrm{n}=504$ & 0,751 & $\mathrm{n}=504$ & 0,783 \\
\hline
\end{tabular}

Veri madenciliği en genel ifade ile iki aşamadan oluşur. İlk aşama veri önişleme için kullanılır, yani veri kullanıma uygun bir formatta hazırlanır (Han vd., 2006; Bramer, 2007; Olson vd., 2008). Diğer aşama ise gizli bilgileri, örüntüleri veya kuralları elde etmek için kullanılan yöntemler bütünüdür (Aggarwal, 2015; Han vd., 2006).

\subsection{Veri Önişleme}

Sürekli artan veri araştırmalar için büyük bir kaynak avantajı sağlasa da aynı zamanda heterojen veri kümeleri elde etmemize neden olmaktadır. Doğal veriler, farklı kaynaklardan ve genellikle planlanmadan oluştuğundan gürültülü, eksik ve tutarsızlıkları da beraberinde getirmektedir (Han vd., 2006). Bu problemleri ortadan kaldırmak için ham veri seti üzerinde birtakım işlemler yapılmalıdır. Böylece ön işlemden geçirilmiş ham veri, veri madenciliği uygulamasını kolay, hızlı ve verimli hale getirebilecektir. Önceki araştırmalar incelendiğinde çok sayıda veri ön işleme tekniği göze çarpmaktadır, hemen hepsinin ortak amacı veri kalitesini artırmaktır. Kullanılan veri ön işleme teknikleri amaçları bakımından sınıflandırıldığında, veri temizleme, veri birleştirme, veri değiştirme ve veri azaltma kategorileri altında toplanmaktadır.

Veri temizleme için gerçekleştirilen ön işleme yöntemleri genellikle gürültüyü gidermek ve verilerdeki tutarsızlıkları düzeltmek için uygulanmaktadır (Han vd., 2006; Olson vd., 2008). Bu aşamada ham veri de eksik veri tamamlama, hatalı verileri düzeltme, tutarsız verileri kaldırma gibi yöntemler uygulanmaktadır. Veri birleştirme, birden fazla kaynaktan gelen verileri, veri ambarı gibi tutarlı bir veri deposunda birleştirme amacıyla uygulanmaktadır (Han vd., 2006; Aggarwal, 2015; Wang ve Wang, 2010). Veri değiştirmede ise genellikle sürekli verilerin kategorik hale getirilmesi veya normalize edilerek ölçeklendirilmesi gibi veri dönüşümleri uygulanmaktadır. Veri azaltma, genellikle araştırma ile ilgisi olmayan gereksiz özellikleri ortadan kaldırarak veya kümeleyerek veri boyutunu azaltılması işlemlerini kapsamaktadır. Bu teknikler genellikle tek başına kullanılmazlar ve birlikte çalışmaktadırlar. Her veri madenciliği algoritmasının başarısının, büyük ölçüde veri önişleme kalitesine bağlı olduğu iyi bilinmektedir (Zhang ve Lu, 2007; Liu vd., 1998). Bu çalışmada, uygulanan veri ön işleme adımları sırası ile verilmiştir.

\subsection{Veri Azaltma}

Çalışmada katılımcılara 25 maddeden oluşan bir ölçek sunulmuş (Van Dyne vd., 2003; Shanock vd., 2019) fakat bu maddeler toplamda 4 faktör altında toplanmıştır. Bu işlem faktörlerde oluşan yükleri tespit etmek amacıyla ilgili maddelerin ortalamaları alınmıştır.

F1 $($ Kabullenici $)=$ Madde Ortalaması $(1,2,3,4,5)$,

F2 $($ Korunmac1 $)=$ Madde Ortalamas1 $(6,7,8,9,10)$,

F3 $($ Korumac1 $)=$ Madde Ortalaması $(11,12,13,14,15)$,

F4 $($ Destek $)=$ Madde Ortalamas1 $(16,17,18,19,20,21,22,23,24,25)$.

Algılanan örgütsel destek ölçeği Shanock vd. (2019) tarafından geliştirilen 10 maddeden oluşan tek faktörlü bir ölçektir.

\subsection{Veri Değiștirme}

Çalışmada kullanılan ölçek 7'li likert tarzında hazırlanmıştır. Katılımcılardan alınan cevaplar kategorik olsa da, ortalamalar alınarak elde edilen faktör değerleri sürekli hale gelmiştir. Bu sebeple katılımcılardan elde edilen cevaplar (veri azaltma işleminden sonra elde edilen faktör değerleri) Eşit Derinlikli Gruplama Metodu (Han vd., 2011) ile tekrar kategorik hale getirilmiştir. Özellikle veri madenciliği yöntemlerinden sınıflama, kümeleme ve birliktelik algoritmaları uygulanılırken çıktı kümelerinin etiketlerinin dengeli dağılması beklenmektedir. Örneğin veri kümesi \%99-\%1 olacak şekilde iki farklı 
etikete sahipse hiçbir algoritma kullanmadan tüm veriler ilk kümeye ait olarak kabul edildiğinde $\% 99$ doğruluk oranına sahip bir kümeleme gerçekleştirilmiş olmaktadır. Bu sebeple algoritmanın gerçek performansını ortaya çıkarabilmek için etiket sınıflarının dengeli olması önem arz etmektedir.

Veri setinin etiketleri sürekli olduğu durumda bu etiketleri ayrıklaştırmak tahmin gücünü arttırmanın en iyi yoludur (Goldrath vd.,1988). Verilerin ayrıklaştırılması için en çok kullanılan iki yöntem, eşit genişlikli ve eşit derinlikli gruplama metotlarıdır (Han, vd., 2011). Eşit genişlikli gruplama metodu verinin belli bir aralıktaki değişimini inceleyebilmek için araştırmacı tarafından belirlenen aralıklara ayrılmasıdır. Veri kümesinde açık uçlu olarak toplanan yaş değişkeninin 20-24, 25-29, 30-34 ... şeklinde ayrıklaştırılması eşit genişlik metoduna örnek olarak gösterilebilir. Eşit genişlikli gruplama yönteminde elde edilen sınıfların içerisinde kalan veri sayısı değil, sınıfların genişliğinin eşit olması önemlidir. Böylece, önceden belirlenen sınıflara göre etiketleme gerçekleştirilmiş olur. Eşit derinlikli gruplama metodunda ise oluşan veri genişliği yerine önemli olan her bir etiket sınıfında yer alan veri sayısıdır. Bu yöntemde sınıflar eşit ya da birbirine çok yakın sayıda veriden oluşmaktadır. Elde edilen verilerde çok sayıda eşit değere sahip veri bulunabileceğinden, her sınıfta eşit sayıda veri olması mümkün olmayabilir. Etiket sınıfları arasında sınır olarak belirlenmiş değere eşit olan veriler farklı kümelere atanmazlar, bu sebeple veri sayılarındaki eşitlik bozulmaktadır.

İki yöntem arasındaki farkları daha iyi anlayabilmek için örnek veri seti: 18, 18, 19, 20, 20, 20, 21, 24, 25, 27, 29, 30, 30, 30, 43, 44 olmak üzere bu veri setinin eşit genişlik ve eşit derinlik yöntemlerine göre ayrıklaştırılmış halleri, oluşan küme sınırları, küme genişlikleri ve küme derinlikleri Tablo 3'de gösterilmiştir.

Tablo 3

Eşit genişlikli ve eşit derinlikli gruplama metodu örnek veri seti

\begin{tabular}{|c|c|c|c|c|c|}
\hline Metot & Etiketler & Oluşan Küme Verileri & $\begin{array}{l}\text { Oluşan Küme } \\
\text { Sinırları }\end{array}$ & $\begin{array}{c}\text { Küme } \\
\text { Genişlikleri } \\
(\text { maks-min+1) }\end{array}$ & $\begin{array}{c}\text { Küime } \\
\text { Derinlikleri } \\
\text { (Veri sayısı) }\end{array}$ \\
\hline \multirow{3}{*}{$\begin{array}{l}\text { Eşit Genişlikli Gruplama } \\
\text { (Equal Width Binning) }\end{array}$} & Sinif 1 & $18,18,19,20,20,20,21,24,25$ & $18-26$ & 9 & 9 \\
\hline & Sinif 2 & $27,29,30,30,30$ & $27-35$ & 9 & 5 \\
\hline & Sinif 3 & 43,44 & $36-45$ & 9 & 2 \\
\hline \multirow{3}{*}{$\begin{array}{l}\text { Eşit Derinlikli Gruplama } \\
\text { (Equal Depth Binning) }\end{array}$} & Sinif 1 & $18,18,19,20,20,20$ & $18-20$ & 3 & 6 \\
\hline & Sinif 2 & $21,24,25,27,29$ & $21-29$ & 9 & 5 \\
\hline & Sinif 3 & $30,30,30,43,44$ & $30-44$ & 15 & 5 \\
\hline
\end{tabular}

Buradan elde edilen veriler, faktörler, kategoriler, sınırlar, kategori kapsamında ele alınan katılımcı sayısı ve son olarak da her bir kategorinin gerçek alt ve üst sınırı Tablo 4'de verilmiştir.

Tablo 4

Kategorik veri özeti tablosu

\begin{tabular}{|c|c|c|c|c|c|c|c|}
\hline Ölçek & Faktör & Seviye & Sinırlar & $\mathbf{n}$ & Yüzde & $\min$ & maks \\
\hline \multirow{9}{*}{ Örgütsel Sessizlik } & \multirow{3}{*}{ Kabullenici } & Düşük & 1-199 & 199 & $39,48 \%$ & 1,00 & 3,40 \\
\hline & & Orta & $200-352$ & 153 & $30,36 \%$ & 3,41 & 4,20 \\
\hline & & Yüksek & $353-504$ & 152 & $30,16 \%$ & 4,21 & 7,00 \\
\hline & \multirow{3}{*}{ Korunmacı } & Düşük & $1-186$ & 186 & $36,90 \%$ & 1,00 & 3,40 \\
\hline & & Orta & $187-354$ & 168 & $33,33 \%$ & 3,41 & 4,20 \\
\hline & & Yüksek & $355-504$ & 150 & $29,76 \%$ & 4,21 & 7,00 \\
\hline & \multirow{3}{*}{ Korumac1 } & Düşük & $1-185$ & 185 & $36,71 \%$ & 1,00 & 3,40 \\
\hline & & Orta & 186-349 & 164 & $32,54 \%$ & 3,41 & 4,20 \\
\hline & & Yüksek & $350-504$ & 155 & $30,75 \%$ & 4,21 & 6,20 \\
\hline \multirow{3}{*}{$\begin{array}{l}\text { Algılanan } \\
\text { Örgütsel Destek }\end{array}$} & \multirow{3}{*}{ Destek } & Düşük & $1-175$ & 175 & $34,72 \%$ & 1,00 & 3,60 \\
\hline & & Orta & $176-351$ & 176 & $34,92 \%$ & 3,61 & 4,30 \\
\hline & & Yüksek & $352-504$ & 153 & $30,36 \%$ & 4,31 & 7,00 \\
\hline
\end{tabular}

\subsection{Birliktelik Kuralı Madenciliği}

Birliktelik kuralı madenciliği, veri tabanında bazı asgari destek ve asgari güven kısıtlamalarını karşılayan tüm kuralları bulmaya yarayan bir analizdir (Agrawal ve Srikant, 1994). Birliktelik kuralı madenciliğinde amaç, önceden belirlenmemiş ve hatta gizli kalmış ilişkilerin ortaya çıkarılmasının sağlanmasıdır. İlişki kuralları, aslen birkaç üründen oluşan bir işlemi 
açıklayan satış noktası verilerinden türetilmiştir (Linoff ve Berry, 2011). Birliktelik analizi genellikle perakende alışveriş sepetleri için ortaya atılmış bir fikir olsa da farklı alanlarda oluşan ilişkilendirme kurallarını belirlemek için de kullanılmıştır. Günümüzde, otel rezervasyonları, telekomünikasyon hizmetleri, bankacılık ürünleri (Linoff ve Berry, 2011), olası tedavi kombinasyonlarında oluşan komplikasyonların tahmini, sahtekârlık ya da dolandırıcılık içeren işlemlerin tespiti gibi birçok alanda birliktelik analizleri kullanılmaktadır. Bu çalışmada çalışanların örgütsel sessizlik ve algılanan örgütsel deste ölçeklerinin faktörleri doğrultusunda oluşan birliktelikler incelenmiş ve çalışanların profilleri belirlenmeye çalışılmıştır. Birliktelik analizlerinin bu kullanım şekliyle etkili bir yaklaşım sergilenmiştir.

\subsection{Apriori Algoritması}

Apriori algoritması, birliktelik gözlenen aday veri kümelerinin ne kadar sık rastlandığını ele alarak veri kümesinde diğer aday alt kümelere doğru ilerleme gösterir. Böylece en sık rastlanan birlikteliklerden daha az rastlanan birlikteliklere doğru kademeli bir tarama sağlamaktadır. Apriori algoritmasının taslak kodları Tablo 5'de verilmiştir.

Tablo 5

Apriori Algoritması taslak kodları (Aggarwal, 2015; Agrawal ve Srikant, 1994)

$\mathrm{C}_{\mathrm{k}}$ : Aday veri seti ( $\mathrm{k}$; boyutu göstermektedir.)

$\mathrm{L}_{\mathrm{k}}$ : Sik rastlanan veri seti ( $\mathrm{k}$; boyutu göstermektedir.)

begin

$\mathbf{L 1}=\{1$ elemanlı sık rastlanan veri seti $\}$

for $\left(\mathrm{k}=1 ; \mathrm{L}_{\mathrm{k}} !=\emptyset ; \mathrm{k}++\right)$ do begin

$\mathrm{C}_{\mathrm{k}+1}=\mathrm{L}_{\mathrm{k}}$ kümesinden aday küme üret;

for veri setindeki tüm işlemler için tekrarla do

$\mathrm{C}_{\mathrm{k}+1}$ de yer alan tüm adayların sayısını arttır

$\mathbf{L k}+\mathbf{1}=\mathbf{C k}+\mathbf{1}$ de ki minimum destek şartını sağlayan aday kümesi

end

return $U_{k} L_{k}$

Budama (Pruning): Herhangi bir alt küme minimum destek şartını sağlayan yeterli sıklığa sahip değilse kümeden çıkar.

end)

4.7.1 Apriori Algoritması ile Birliktelik Kuralları Oluşturma

Bir veri seti içinde sık kullanılan öğe kümelerini belirlemek için Agrawal ve Srikant tarafından önerilen algoritma güven (confidence), destek (support) ve kaldıraç (lift) değerlerine göre birliktelikleri oluşturmaktadır.

$$
\operatorname{Destek}(\mathrm{X} \rightarrow \mathrm{Y})=P(X \cap Y)
$$

Veri seti içerisinde X ve Y durumlarının birlikte gerçekleşme olasılığının değeri destek olarak tanımlanmaktadır ve Eşt.1 de ki gibi hesaplanmaktadır.

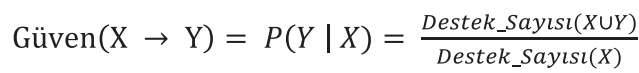

Veri seti içerisinde X'in gerçekleştiği örneklem de Y'nin de gerçekleşmesi durumu bir koşullu olasılık belirtmektedir. Bu koşullu olasılık değeri Eşt.2 de ki gibi hesaplanmaktadır.

$$
\text { Kaldıraç }(\mathrm{X} \rightarrow \mathrm{Y})=\frac{P(X \cup Y)}{P(X) P(Y)}
$$

Destek ve Güven değerleri sık kullanılan öğe gruplarını belirlemede oldukça elverişli olsa da ilgi çekici olmayan ilişki kurallarını filtrelemek için yetersiz kalmaktadır. Kaldıraç destek, güven ve veri setleri arasındaki ilişkiyi ortaya çıkarmak için kullanılmaktadır. Kaldıraç, bağımsız veri setleri için kolaylıkla Eşt.3 de ki gibi hesaplanabilmektedir. Kaldıraç değeri 
1'den küçükse X ve Y durumları negatif korelasyonludur, 1'den büyükse pozitif korelasyonludur. Diğer taraftan eğer kaldıraç değeri 1'e eşit hesaplanırsa $\mathrm{X}$ ve $\mathrm{Y}$ durumları bağımsızdır ve aralarında bir ilişki yoktur şeklinde yorumlanmaktadır. Korelasyon analizi yalnızca ilişkinin yönünü ve gücünü göstermektedir, elde edilen kaldıraç değerleri ise bir durumun gerçekleşmesinin diğer durumu ne kadar etkilediğini göstermektedir (Han vd., 2011).

\section{BULGULAR}

Çalışmanın sonucunda, anket ile toplanan verilerden yola çıkarak Örgütsel Sessizlik faktörleri ile Algılanan Örgütsel Destek faktörü arasındaki en sık gerçekleşen birliktelikleri tespit ederek bir profil çıkarımı yapmaktır. Bu sebeple veri ön işleme adımları yapılarak, Veri Madenciliği için uygun olan formata dönüştürülmüştür. İlk olarak yalnızca Örgütsel Sessizlik faktörlerine minimum 0,5 güven seviyesinde Apriori Algoritması uygulanmıştır (Tablo 6).Uygulanan Apriori algoritmasında kurallar güven parametresine göre sıralanmıştır. Destek değeri ise 1'den başlanarak her yeni kural arama sürecinde 0,05 birim azaltılmış ve minimum destek değeri 0,10 olarak belirlenmiştir. Her bir kural için elde edilen destek değeri Tablo 6'da verilmiştir.

Tablo 6

Örgütsel Sessizlik ölçeği faktörleri birliktelik kuralları

\begin{tabular}{|c|c|c|c|c|}
\hline \multicolumn{5}{|c|}{ ÖRGÜTSEL SESSIZLIK ÖLÇEĞI } \\
\hline \multicolumn{2}{|c|}{ Birliktelik Kuralları } & Güven & Destek & Kaldıraç \\
\hline 1. Korunmacı (Düşük), Korumacı (Düşük) 87 & $==>$ Kabullenici (Düşük) 66 & 0,76 & 0,131 & 1,92 \\
\hline 2. Kabullenici (Düşük), Korumacı (Düşük) 91 & $==>$ Korunmac1 (Düşük) 66 & 0,73 & 0,131 & 1,97 \\
\hline 3. Kabullenici (Düşük), Korunmacı (Düşük) 110 & $==>$ Korumacı (Düşük) 66 & 0,60 & 0,131 & 1,77 \\
\hline 4. Korunmacı (Düşük) 186 & $==>$ Kabullenici (Düşük) 110 & 0,59 & 0,218 & 1,50 \\
\hline 5. Kabullenici (Düşük) 199 & $==>$ Korunmacı (Düşük) 110 & 0,55 & 0,218 & 1,50 \\
\hline 6. Korumacı (Düşük) 171 & $==>$ Kabullenici (Düşük) 91 & 0,53 & 0,181 & 1,35 \\
\hline 7. Korumac1 (Düşük) 171 & $==>$ Korunmacı (Düşük) 87 & 0,51 & 0,173 & 1,38 \\
\hline
\end{tabular}

Tablo 7 örgütsel sessizlik ölçeği faktörlerinin kendi aralarında oluşturdukları birliktelik ilişkilerini belirttiğinden dolayı $\mathrm{H}_{4}$ hipotezinin olası senaryolarının doğrulandığı kurallar elde edilmiştir. Veri setinde korunmacı ve korumacı faktörlerinin ikisi de düşük olan 87 gözlem bulunmaktadır. Bu iki faktörde düşük iken kabullenici faktörü de düşük olan 66 gözlem olarak belirlenmiştir. Dolayısı ile korunmacı ve korumacı faktörleri düşük olan gözlemlerin \% 76'sında aynı zamanda kabullenici faktörü de düşüktür. Veri setinde kabullenici ve korumacı faktörlerinin ikisi de düşük olan 91 gözlem bulunmaktadır. Bu iki faktörde düşük iken korunmacı faktörü de düşük olan 66 gözlem olarak belirlenmiştir. Dolayısı ile kabullenici ve korumact faktörleri düşük olan gözlemlerin \% 73'ünde aynı zamanda korunmacı faktörü de düşüktür. Veri setinde kabullenici ve korunmacı faktörlerinin ikisi de düşük olan 110 gözlem bulunmaktadır. Bu iki faktörde düşük iken Korumacı faktörü de düşük olan 66 gözlem olarak belirlenmiştir. Dolayısı ile korunmacı ve kabullenici faktörleri düşük olan gözlemlerin \% 60'ında aynı zamanda korumacı faktörü de düşüktür.

Tablo 7

Örgütsel Sessizlik ve Algılanan Örgütsel Destek Ölçeği faktörleri birliktelik kuralları ÖRGÜTSEL SESSIZLIK ÖLÇEĞI VE ALGILANAN ÖRGÜTSEL DESTEK ÖLÇEĞI

\begin{tabular}{|c|c|c|c|c|}
\hline \multicolumn{2}{|c|}{ Birliktelik Kuralları } & \multirow{2}{*}{$\begin{array}{c}\text { Güven } \\
0,90\end{array}$} & \multirow{2}{*}{$\begin{array}{c}\text { Destek } \\
0,163\end{array}$} & \multirow{2}{*}{$\begin{array}{c}\text { Kaldıraç } \\
2,60\end{array}$} \\
\hline 1. Kabullenici (Düşük), Korumacı (Düşük) 91 & $==>$ Destek (Düşük) 82 & & & \\
\hline 2. Korunmacı (Düşük), Korumacı (Düşük) 87 & $==>$ Destek (Düşük) 78 & 0,90 & 0,155 & 2,58 \\
\hline 3. Kabullenici (Düşük), Destek (Düşük) 96 & $==>$ Korumacı (Düşük) 82 & 0,85 & 0,163 & 2,52 \\
\hline 4. Korunmacı (Düşük), Destek (Düşük) 93 & $==>$ Korumacı (Düşük) 78 & 0,84 & 0,155 & 2,47 \\
\hline 5. Korumacı (Düşük) 171 & ==> Destek (Düşük) 139 & 0,81 & 0,276 & 2,34 \\
\hline 6. Destek (Düşük) 175 & $==>$ Korumac1 (Düşük) 139 & 0,79 & 0,276 & 2,34 \\
\hline 7. Destek (Yüksek) 127 & $==>$ Korumacı (Yüksek) 94 & 0,74 & 0,187 & 2,38 \\
\hline 8. Korumac1 (Orta) 176 & $==>$ Destek $($ Orta) 111 & 0,63 & 0,220 & 1,57 \\
\hline 9. Korumacı (Yüksek) 157 & $==>$ Destek (Yüksek) 94 & 0,60 & 0,187 & 2,38 \\
\hline 10. Korunmac1 (Düşük) 186 & $==>$ Kabullenici (Düşük) 110 & 0,59 & 0,218 & 1,50 \\
\hline
\end{tabular}

İki ölçek faktörleri beraber incelendiğinde faktörler arasında oldukça çarpıcı sonuçlar elde edilmektedir. $\mathrm{H}_{6}$ hipotezinde belirtildiği gibi elde edilen 1. kuralda kabullenici ve korumacı faktörleri düşük olan 91 gözlemin \% 90’1 yani 82 gözlemde 
destek faktörünün de düşük olduğu, $\mathrm{H}_{7}$ hipotezinde belirtildiği gibi elde edilen 2. kuralda korunmacı ve korumacı faktörleri düşük olan 87 gözlemin \% 90’1 yani 78 gözlemde destek faktörünün de düşük olduğu gözlemlenmiştir. Diğer taraftan, $\mathrm{H}_{6}$ hipotezinin çift yönlü olduğunu gösteren 3. kural, kabullenici ve destek faktörleri düşük olan 96 gözlemin \% 85’i yani 82 gözlemde korumacı faktörünün de düşük olduğu ve benzer şekilde $\mathrm{H}_{7}$ hipotezinin çift yönlü olduğunu gösteren 4. kural, korunmacı ve destek faktörleri düşük olan 93 gözlemin \% 84’1 yani 78 gözlemde korumacı faktörünün de düşük olduğu ilişkileri gözlemlenmiş̧tir. Yapılan değerlendirmede 0,50 ve üzeri eşik değere göre oluşan birliktelik kuralları kabul edildiğinden dolayı $\mathrm{H}_{5}$ ve $\mathrm{H}_{8}$ hipotezleri ile ilgili bir kural elde edilmemiştir.

$\mathrm{Bu}$ çoklu ilişkilerin dışında ayrıca destek faktörü ile diğer faktörler arasında ikili ilişkilerin yer aldığ 1 kurallarda saptanmıştır. $\mathrm{H}_{3}$ hipotezinin, hemen her seviyede farklı kurallar elde edilmiş olması sebebiyle ön plana çıktığı dikkat çekmektedir. $\mathrm{H}_{3}$ hipotezinde belirtildiği gibi elde edilen 5. kuralda korumac 1 faktörünün düşük olduğu 171 gözlemin \% 81’i yani 139 gözlemde destek faktörünün de düşük olduğu, $\mathrm{H}_{3}$ hipotezinin çift yönlü olduğunu gösteren 6. kuralda destek faktörünün düşük olduğu 175 gözlemin \% 79'u yani 139 gözlemde korumacı faktörünün de düşük olduğu gözlemlenmiş̧ir. Benzer şekilde $\mathrm{H}_{3}$ hipotezinde belirtildiği gibi elde edilen 7. kuralda destek faktörünün yüksek olduğu 127 gözlemin \% 74’ü yani 94 gözlemde korumacı faktörünün de yüksek olduğu, $\mathrm{H}_{3}$ hipotezinin çift yönlü olduğunu gösteren 9. kuralda korumacı faktörünün yüksek olduğu 157 gözlemin \% 60’1 yani 94 gözlemde destek faktörünün de yüksek olduğu ilişkileri gözlemlenmiştir. Son olarak yine $\mathrm{H}_{3}$ hipotezinde belirtildiği gibi elde edilen 8. kuralda korumacı faktörünün orta olduğu 176 gözlemin \% 63 'ü yani 111 gözlemde destek faktörünün de orta olduğu gözlemlenmiştir. Yapılan değerlendirmede 0,50 ve üzeri eşik değere göre oluşan birliktelik kuralları kabul edildiğinden dolayı ikili ilişkileri içeren $\mathrm{H}_{1}$ ve $\mathrm{H}_{2}$ hipotezleri ile ilgili bir kural elde edilmemiştir.

\section{SONUÇ}

$\mathrm{Bu}$ araştırma, çalışan davranışının çok boyutlu olarak modellenmesi ile oluşturulan başarılı modellerin rekabet avantajı ve işgücü planlaması başta olmak üzere çok değerli kazanımları beraberinde getireceği fikri üzerine tasarlanmıştır. Bu doğrultuda, çalışanın algıladığı örgütsel destek ve çalışan sessizliği arasındaki keşfedilmemiş ilişkilerin belirlenmesi amacıyla veri madenciliği tekniklerinden yararlanılmıştır. Araştırma sonuçları örgütsel destek ve çalışan sessizliği bağlamında özgün ve daha önce belirlenmemiş ilişkilerin varlı̆̆ını ortaya koymaktadır. Bu durum, insan kaynakları yönetiminin tek bir paradigmanın ötesinde taşımak gerektiği ve farklı yaklaşımların birlikte ele alınarak önemli çıkarımlar yapılabileceği düşüncesini (Nechanska vd., 2020) desteklemektedir. Araştırmaya konu olan bu iki önemli örgütsel olgunun böyle bir ilişkisel bir çerçevede ele alınması örgütsel davranış ve insan kaynakları araştırmacı için yeni bir kapı aralamaktadır. Çalışan tutum ve davranışlarının modellenmesi bu alandaki araştırmacıların belirli bağlamlarda çıkarımlar yapmasına olanak sağlayacaktır.

Yüzde $86.50 \%$ başarı oranı ile oluşturulan model, araştırma ile elde edilen bulgular araştırmanın oldukça soyut görünen çalışan tutumlarının ve profillerinin açığa çıkarılması için yeni ve etkili bir yaklaşım sunduğunu göstermektedir. Nitekim elde edilen birliktelik kuralları için \%50 eşik değer olarak belirlenmiş ve yedi kural tespit edilmiştir. Örgütsel sessizlik ve algılanan örgütsel destek ölçeklerinin kendi aralarındaki birliktelik kurallarının analizi ise 10 kuralın varlığına işaret etmektedir. İlk 5 kural için $80 \%$ üzerinde birliktelik ilişkisi olduğu gözlemlenmiştir. Ayrıca, örgütsel sessizlik ölçeğinde yer alan korumacı faktörü ile hemen her seviyede ve çift yönlü olarak algılanan örgütsel destek ölçeği arasında oluşan birliktelik kuralları çalışan profilleri için yüksek önem düzeyinde bir çıkarım yapılmasını sağlamaktadır. Bu noktada, çalışan sessizliği ve algılanan örgütsel destek İlişkisi bölümünde yer verilen literatüre önemli bir katkı sunmakta ve yüksek önem düzeyinde bir çıkarım yapılmasını sağlayarak çalışan sessizliğinin nedenleri daha iyi anlamak için yeni firsatlar sunmaktadır. İlgili literatür özellikle çalışan sessizliğinin ortaya çıkma biçimleri ve öncüllerinin neler olduğu konusunda yeterli olgunluğu erişmediği düşünüldüğünde (Brinsfield, 2013), elde edilen sonuçlar çalışan sessizliği türleri (özellikle korumacı sessizlik) ile ilgili gelecekte yapılacak araştırmalar için önemli bir temel oluşturmaktadır. Bununla birlikte, araştırma kapsamında en yüksek birliktelik oranına ulaşan 1. kuralda yer alan kabullenici faktörünün tek başına algılanan destek faktörü ile bir kural oluşturamaması fakat korumacı faktörü ile bir arada ele alındığında en yüksek birliktelik oranına ulaşması çalışmanın gizli örüntülerinden bir olarak karşımıza çıkmaktadır. Kabullenici ve Korumacı faktörleri arasındaki kural incelendiğinde, Korumacı faktörünün düşük olduğu 171 gözlemin \% 51’i yani 87 gözlemde kabullenici faktörününde düşük olduğu tek yönlü bir kural ortaya çıkmaktadır. Söz konusu faktörler arasında ki birliktelik ilişkisi araştırmanın literatüre sağladığı bir diğer 
özgün katkıyı oluşturmakta ve yapılabilecek araştırmalar için bir kapı aralamaktadır. Nitekim, bu durum çalışan profili çalışmalarında gizli kural ve örüntülerin önemini açıkça ortaya koymaktadır. Son olarak, yazarlar salt mavi yaka çalışan örneklemi üzerinden hareket edilen bu araştırmanın genişletilerek beyaz yaka çalışanları da kapsayan çalışmalar yapılmasının önemli bulguları beraberinde getirebileceğini değerlendirmektedir. Benzer araştırmaların Chou ve Chang (2020) gibi araştırmalarda ileri sürülen sessizlik boyutları kullanılarak yapılmasının burada belirlenen ilişkilerin tartışılmasına olanak sağlayacağı değerlendirilmektedir.

Hakem Değerlendirmesi: Dış bağımsız.

Çıkar Çatışması: Yazarlar çıkar çatışması bildirmemiştir

Finansal Destek: Yazarlar bu çalışma için finansal destek almadığını beyan etmiştir.

Peer-review: Externally peer-reviewed.

Conflict of Interest: The authors have no conflict of interest to declare.

Grant Support: The authors declared that this study has received no financial support.

\section{Kaynaklar/References}

Aggarwal, C. (2015). Data mining: the textbook. Springer. doi: 10.1007/978-3-319-14142-8

Agrawal, R., \& Srikant, R. (1994). Fast algorithms for mining association rules. In Proc. 20th int. conf. very large data bases, VLDB (Vol. 1215, pp. 487-499).

Akçin, K. vd. (2017). Effect of Perceived Organizational Support On Organizational Silence and Task Performance: A Study on Academicians. Journal of Global Strategic Management, vol.11, pp.35-44.

Allen, D.G., Shore, L.M., ve Griffeth, R.W. (2003) The role of perceived organizational support and supportive human resource practices in the turnover process. Journal of Management, 29, 99-118.

Beheshtifar vd. (2012). Destructive role of employee silence in organizational success, International Journal of Academic Research in Business and Social Sciences, 2 (11): 275-282.

Beheshtifar, Malikeh \& Borhani, Hossein \& Nekoei-Moghadam, Mahmood. (2012). Destructive Role of Employee Silence in Organizational Success. International Journal of Academic Research in Business and Social Sciences. 2.

Bramer, M. (2007). Principles of data mining (Vol. 180). London: Springer. ISBN : 978-1-4471-7306-9

Brinsfield, C. T. (2013). Employee silence motives: Investigation of dimensionality and development of measure. Journal of Organizational Behavior, 34, 671-697. doi:10.1002/job.1829

Chen, T., Hao, S., Ding, K., Feng, X., Li, G., \& Liang, X. (2020). The impact of organizational support on employee performance. Employee Relations: The International Journal.

Chen, Zhixia \& Eisenberger, Robert \& Johnson, Kelly \& Sucharski, Ivan \& Aselage, Justin. (2009). Perceived Organizational Support and Extra-Role Performance: Which Leads to Which?. The Journal of social psychology. 149. 119-24. 10.3200/SOCP.149.1.119-124.

Chou, S. Y., \& Chang, T. (2017). Employee silence and silence antecedents: A theoretical classification. International Journal of Business Communication. https://doi.org/10.1177/ 2329488417703301.

Chou, S. Y., \& Chang, T. (2020). Employee Silence and Silence Antecedents: A Theoretical Classification. International Journal of Business Communication, 57(3), 401-426. https://doi.org/10.1177/2329488417703301

Çınar, O., Karcığlu, F. \& Alioğulları, Z. (2013). The relationship between organizational silence and organizational citizenship behavior: A survey study in the province of Erzurum, Turkey. Procedia - Social and Behavioral Sciences. 99. 314-321. 10.1016/j.sbspro.2013.10.499.

Donaghey, J., Cullinane, N., Dundon, T., \& Wilkinson, A. (2011). Reconceptualising employee silence: problems and prognosis. Work, Employment and Society, 25(1), 51-67. https://doi.org/10.1177/0950017010389239

Dong, X. T., \& Chung, Y. W. (2020). The Mediating Effect of Perceived Stress and Moderating Effect of Trust for the Relationship Between Employee Silence and Behavioral Outcomes. Psychological Reports, 0033294120942914.

Duan, W., Tang, X., Li, Y., Cheng, X., \& Zhang, H. (2020). Perceived organizational support and employee creativity: The mediation role of calling. Creativity Research Journal, 1-9.

Dyne, L. V., Ang, S., \& Botero, I. C. (2003). Conceptualizing employee silence and employee voice as multidimensional constructs. Journal of management studies, 40(6), 1359-1392. https://doi.org/10.1111/1467-6486.00384

Eisenberger, R. L., Fasolo, P., \& Davis-LaMastro, V. (1990). Perceived organizational support and employee diligence, commitment, and innovation. The Journal of Applied Psychology, 75, 51-59.

Eisenberger, R., \& Stinglhamber, F. (2011). Perceived organizational support: Fostering enthusiastic and productive employees. Washington, DC: American Psychological Asso- ciation. http://dx.doi.org/10.1037/12318-000

Eisenberger, R., Huntington, R., Hutchison, S., \& Sowa, D. (1986). Perceived organizational support. Journal of Applied Psychology, 71 , 500-507. http://dx.doi.org/10.1037/0021- 9010.71.3.500 
Goldrath, N., Zimes, R., \& Vered, Z. (1988). Analysis of Doppler-obtained velocity curves in functional evaluation of mechanical prosthetic valves in the mitral and aortic positions. Journal of the American Society of Echocardiography, 1(3), 211-225. https://doi.org/10.1016/S0894-7317(88)80077-4

Han, J., Pei, J., \& Kamber, M. (2011). Data mining: concepts and techniques. Elsevier. ISBN 13: 978-1-55860-901-3 ISBN 10: 1-55860-901-6

Hayton, J. C., Carnabuci, G., \& Eisenberger, R. (2012). With a little help from my colleagues: A social embeddedness approach to perceived organizational support. Journal of Orga-nizational Behavior, 33, 235-249. http://dx.doi.org/10.1002/job.755

Hirschman, A. O. (1970). Exit, voice, and loyalty: Reponses to decline in firms, organizations, and states. Cambridge, MA: Harvard University Press.

Huang X, Van de Vliert E ve Van Der Vegt G (2005). Breaking the silence culture: stimula- tion of participation and employee opinion withholding cross-nationally. Management and Organization Review 1(3): 459-482.

Imran, M. Y., Elahi, N. S., Abid, G., Ashfaq, F., \& Ilyas, S. (2020). Impact of perceived organizational support on work engagement: Mediating mechanism of thriving and flourishing. Journal of Open Innovation: Technology, Market, and Complexity, 6(3), 82.

Jaweria Khalid \& Jaleel Ahmed (2016) Perceived organizational politics and employee silence: supervisor trust as a moderator, Journal of the Asia Pacific Economy, 21:2, 174-195, DOI: 10.1080/13547860.2015.1092279

Karakaş, Ayhan. (2019). The relationship between perceived supervisor support and the aspects of organizational silence. 8. 1-19.

Kurtessis, J. N., Eisenberger, R., Ford, M. T., Buffardi, L. C., Stewart, K. A., \& Adis, C. S. (2017). Perceived organizational support a meta-analytic evaluation of organizational support theory. Journal of Management, 43, 1854-1884. https://doi.org/10.1177/0149206315575554

LaPiere, R. T. (1934). Attitudes vs. actions. Social forces, 13(2), 230-237. doi: 10.2307/2570339

Levinson, H. (1965). Reciprocation: The relationship between man and organization. Admin-istrative Science Quarterly, 9, 370-390. http://dx.doi. org/10.2307/2391032

Linoff, G. S., \& Berry, M. J. (2011). Data mining techniques: for marketing, sales, and customer relationship management. John Wiley \& Sons. ISBN: 978-0-470-65093-6

Liu, B., Hsu, W., \& Ma, Y. (1998). Integrating classification and association rule mining. In KDD (Vol. 98, pp. 80-86).

Milliken FJ, Morrison EW, Hewlin PF. (2003). An exploratory study of employee silence: Issues that employees don't communicate upward and why. Journal of Management Studies, 40, 1453-1476.

Morrison EW, Milliken FJ. (2000). Organizational silence: A barrier to change and devel- opment in a pluralistic world. Academy of Management Review, $25,706-725$.

Mousa, M., Abdelgaffar, H. A., Aboramadan, M., \& Chaouali, W. (2020). Narcissistic Leadership, Employee Silence, and Organizational Cynicism: A Study of Physicians in Egyptian Public Hospitals. International Journal of Public Administration, 1-10.

Nechanska E, Hughes E and Dundon (2018) Towards an integration of employee voice and silence. Human Resource Management Review. Epub ahead of print 7 December 2018. DOI: 10.1016/j.hrmr.2018.11.002

Olson, D. L., \& Delen, D. (2008). Advanced data mining techniques. Springer Science \& Business Media. ISBN: 978-3-540-76916-3 e-ISBN: 978-3-540-76917-0

Pedro Neves Robert Eisenberger (2014). Perceived organizational support and risk taking, Journal of Managerial Psychology, Vol. 29 Iss 2 pp. 187-205 http://dx.doi.org/10.1108/JMP-07-2011-0021

Pinder CC. \&Harlos KP. (2001). Employee silence: Quiescence and acquiescence asresponses to perceived injustice. Research in Personnel and Human Resources Management, 20, 331-369.

Rhoades, L., \& Eisenberger, R. (2002). Perceived organizational support: A review of the literature. The Journal of Applied Psychology, 87, 698-714.

Schlenker, B. R. \& Weigold, M. F. (1989). ‘Self-identification and accountability'. In Giacalone, R. A. and Rosenfeld, P. (Eds), Impression Management in the Organization. Hillsdale, NJ: Erlbaum, 21-43.

Schober, P., Boer, C., \& Schwarte, L. A. (2018). Correlation coefficients: appropriate use and interpretation. Anesthesia \& Analgesia, 126(5), $1763-1768$. https://doi.org/10.1213/ANE.0000000000002864

Shanock, L. R., Eisenberger, R., Heggestad, E. D., Malone, G., Clark, L., Dunn, A. M., Kirkland, J., \& Woznyj, H. (2019). Treating employees well: the value of organizational support theory in human resource management. The Psychologist-Manager Journal. Advance online publication. http://dx.doi. org/10.1037/mgr0000088

Shore, L. M., \& Shore, T. H. (1995). Perceived organizational support and organizational justice. In R. S. Cropanzano, \& K. M. Kacmar (Eds.). Organizational politics, justice and support: Managing the social climate of the workplace (pp. 149-164). Wesport, CT: Quorum.

Singh, B. S., \& Malhotra, M. (2015). The mediating role of trust in the relationship between perceived organizational support and silence.International Journal of Scientific and Research Publications, 5(9), 1-10.

Tangirala, S., \& Ramanujam, R. (2008). Employee silence on critical work issues: The cross level effects of procedural justice climate. Personnel Psychology, $61,37-68$.

Tucker, S., Chmiel, N., Turner, N., Hershcovis, M. S. ve Stride, C. B. (2008). Perceived organizational support for safety and employee safety voice: The mediating role of co-worker support for safety. Journal of Occupational Health Psychology, 13(4), 319-330.

Van Dyne, L., Ang, S., \& Botero, I. C. (2003). Conceptualizing employee silence and employee voice as multidimensional constructs. Journal of Management Studies, 40(6), 1359-1392. https://doi.org/10.1111/1467-6486.00384

Wang, C. C., Hsieh, H. H., \& Wang, Y. D. (2020). Abusive supervision and employee engagement and satisfaction: the mediating role of employee silence. Personnel Review.

Wang, H., \& Wang, S. (2010). Mining incomplete survey data through classification. Knowledge and information systems, 24(2), 221-233. https://oi. org/10.1007/s10115-009-0245-8 
Wang, Y. \& Hsieh, H. (2013). Organizational ethical climate, perceived organizational support and employee silence: A cross-level investigation. Human Relations, 66(6), 783-802.

Whiteside, D., \& Barclay, L. (2012). Echoes of silence: Employee silence as a mediator between overall justice and employee outcomes. Journal of Business Ethics, 116, 251-266. doi:10.1007/s10551-012-1467-3

Yu, Y. \& Liu, Q. (2016). The effect of psychological capital and organizational support on innovational behavior and silence behavior of technical innovation personnel in strategic emerging industry. American Journal of Industrial and Business Management, 6, 732-740. doi: 10.4236/ajibm.2016.66067.

Zehir, C. \& Erdogan, E. (2011). The association between organizational silence and ethical leadership through employee performance, Procedia Social and Behavioral Sciences, 24: 1389-1404.

Zhang, N., \& Lu, W. F. (2007). An efficient data preprocessing method for mining customer survey data. In 2007 th IEEE International Conference on Industrial Informatics (Vol. 1, pp. 573-578). IEEE. doi: 10.1109/INDIN.2007.4384821 
